\title{
INOVASI MEDIA PENILAIAN BAHASA ARAB MENGGUNAKAN POWER POINT
}

\author{
Aisyatul Hanun ${ }^{1}$, Amirul Mukminin $^{2}$, Shofwatul Widad ${ }^{3}$ \\ Pendidikan Bahasa Arab, Universitas Ibrahimy Situbondo \\ ${ }^{1}$ hanun89@gmail.com, ${ }^{2}$ mora.mukmin@ gmail.com, ${ }^{3}$ widadadhim@gmail.com
}

\begin{abstract}
Abstrac:
The process stages of innovation evaluation using power points is begun by mudarris' complaint about an inefficient assessment process because it uses an inappropriate instrument, until in 2018 a grading of assessment questions was formed. By continuing to be pursued, evaluated and developed, now the design of power point applications that can be used as an instrument in the implementation of assessments in Arabic learning of female students with implementation practices as follows; students listen to istima' audio, then conclude about what they can understand from the audio they have listened, then students write words that they can remember from what they have listened before, read the qiro'ah texts that have been available on the power point, and finally answer some questions about qawaid. The results of this innovation design can be declared worthy of being a good instrument because it meets the criteria. In addition, the results of this design were also very successful in covering the implementation of the assessment when assessing the skills of the four language skills (maharah), and also the ability of understanding qawaid that students have.
\end{abstract}

Keywords: innovation, assessment, power point.

\section{PENDAHULUAN}

Dalam proses pembelajaran terdapat tiga unsur pokok ; perencanaan, pelaksanaan dan evaluasi. Oleh karenanya penilaian hasil belajar harus dilaksanakan sebagai implementasi dari unsur pokok pembelajaran yang ketiga. Pelaksanaan penilaian hasil belajar memiliki fungsi untuk mengukur sejauh apa tingkat keberhasilan dari pelaksanaan pembelajaran. Baik tingkat keberhasilan dari peserta didik dalam menerima dan memahami materi pembelajaran, keberhasilan para tenaga pengajar dalam proses mentransfer keilmuan, maupun tingkat keberhasilan dari lembaga pendidikan sebagai pihak pelaksana pembelajaran itu sendiri. Sebagaimana menurut Grounlund "penilaian adalah suatu proses yang sistematis dari pengumpulan, analisis, dan interpretasi informasi atau data untuk menentukan sejauh mana peserta didik telah mencapain tujuan pembelajaran".

Seorang penilai atau guru penilai yang baik, berkompeten dan profesional harus memiliki kombinasi ciri-ciri berikut, antara lain: mengetahui dan mengerti teknik pengukuran, metode penilaian, mengerti tentang kondisi sosial dan hakekat objek penilaian, mempunyai kemampuan hubungan kemanusiaan, jujur, serta bertanggung jawab. ${ }^{2}$

Selain tiga unsur pokok di atas, perubahan-perubahan ke arah yang lebih baik juga sangat dibutuhkan dalam proses pembelajaran. Seperti inovasi-inovasi kecil yang dapat diterapkan guna menyesuaikan dengan keadaan zaman. Maka selain menjadi guru profesional yang mampu memenuhi kriteria ideal seorang penilai, hendaknya guru

1 Zainal Arifin, Evaluasi Pembelajaran, (Jakarta: PT Remaja Rosadakarya: 2013), 4.

${ }^{2}$ Farida Yusuf tayibnapis, Evaluasi Program, (Jakarta: PT. Rineka Cipta, 2000), 8. 
juga mampu berinovasi, ${ }^{3}$ memperbaharui rangkaian-rangkaian proses pembelajaran agar suasana kelas terasa lebih menyenangkan, tidak monoton juga lebih up to date.

Pondok Pesantren Darul Lughah Waddirosatil Islamiyah Palenga'an Pamekasan merupakan salah satu Pondok Pesantren yang menyediakan kursus bahasa arab untuk para muhibbat 'arabiyah dan termasuk salah satu dari beberapa pesantren yang berfokus pada pendalaman bahasa Arab di pulau Madura. Pesantren tersebut didirikan dan dipimpin oleh KH. Ach. Ghazali Salim, Lc., M.Hi.

Sehari-hari, santri atau pelajar di Pondok Pesantren tersebut mengikuti pembelajaran dijenjang pendidikan formal sebagaimana biasa. Dan setelah rangkaian pendidikan formal selesai, barulah santri atau pelajar tersebut mengikuti serangkaian kajian keislaman yang telah diatur dan dijadwal oleh para pengurus pesantren bagian pendidikan. Setelah kegiatan kajian keislaman tersebut, barulah santri memasuki kelas sesuai jenjang yang telah ditentukan untuk memulai pembelajaran bahasa Arab. Dan sebagai penunjang kemampuan para santri untuk lebih bisa berbahasa Arab dengan baik dan benar, para santri diwajibkan untuk menggunakan bahasa Arab untuk berkomunikasi sehari-hari.

Dalam pembelajarannya, Pondok Pesantren Darul Lughah Waddirosatil Islamiyah menerapkan praktek pembelajaran yang sangat menyenangkan. Para tenaga pengajar tidak segan segan membawa para peserta didik keluar dari kelas agar pembelajarn tidak terasa menjenuhkan. Bahkan para mudarris juga menyiapkan

\footnotetext{
${ }^{3}$ Inovasi berasal dari kata latin, innovation yang berarti pembaruan dan perubahan. Kata kerjanya innovo yang artinya memperbarui dan mengubah. Inovasi ialah suatu perubahan yang baru yang menuju ke arah perbaikan, yang lain atau berbeda dari apa yang ada sebelumnya, yang dilakukan dengan sengaja dan berencana artinya tidak terjadi secara kebetulan saja. Pendapat lain juga mengatakan bahwa Menurut Ansyar, Nurtain (1991) inovasi adalah gagasan, perbuatan, atau sesuatu yang baru dalam konteks sosial tertentu untuk menjawab masalah yang dihadapi. Fuad Ihsan, Dasar-Dasar Keperndidikan, (Jakarta:PT Rineka Cipta: 2011), 191-192.
}

media yang menarik untuk memancing simpati para pelajar dan mempermudah pelajar mengerti materi pembelajaran dengan cepat.

Dalam pelaksanaan penilaiannya, pondok pesantren tersebut menginovasi media penilaian yang digunakan. Peserta didik tidak lagi mengerjakan butir-butir soal diatas kertas, namun peserta didik diminta untuk menjawab beberapa pertanyaan yang telah dirancang dalam slide-slide power point.

Inovasi penilaian menggunakan power point yang diterapkan di Pondok Pesantren Darul Lughah Waddirosatil Islamiyah ini tidak dilakukan secara kebetulan saja. Inovasi dilakukan melalui berbagai macam pertimbangan dan keputusan dari berbagai pihak kelembagaan. Lalu direncanakan, dirancang, ditetapkan, diterapkan kemudian dievaluasi untuk akhirnya disempurnakan.

Proses inovasi hendaknya dapat menjadikan proses belajar mengajar lebih mudah, baik untuk guru maupun untuk peserta didik sendiri. Maka dibalik proses inovasi sudah pasti ada alasan-alasan mengapa inovasi tersebut dilaksanakan, lalu alasan-alasan yang telah tersedia akan dikaji lebih dalam untuk akhirnya diterapkanlah proses inovasi oleh pihak-pihak lembaga pendidikan. Proses inovasi tidaklah dilakukan secara kebetulan saja, melainkan melalui berbagai macam pertimbangan dan keputusan dari berbagai pihak kelembagaan. Lalu direncanakan, dirancang, ditetapkan, diterapkan kemudian dievaluasi untuk akhirnya disempurnakan.

Aplikasi Microsoft Power Point yang dijadikan sebagai inovasi dalam peniliaan bahasa Arab memiliki keunikan, dimana media tersebut bisa digunakan untuk presentasi atau digunakan sebagai media pendukung dalam proses pembelajaran, di Pondok Pesantren Darul Lughah Waddirosatil Islamiyah dirancang untuk dijadikan media dalam pelaksanaan penilaian.

Keunikan disinilah yang membuat peneliti tertarik untuk mengkaji lebih dalam berkaitan dengan inovasi aplikasi microsoft power point dijadikan sebagai media penilaian dalam pembelajaran Bahasa Arab. Peneliti mengkaji, bagaimana implementasi 
aplikasi microsoft power point dalam penilaian bahasa Arab di Pondok Pesantren Darul Lughah Waddirosatil Islamiyah Akkor Palengaan Pamekasan?

\section{METODE PENELITIAN}

Penelitian ini menggunakan metode penelitian kualitatif, yaitu metode penelitian yang digunakan untuk meneliti pada kondisi obyek yang alamiyah, dimana peneliti adalah sebagai instrumen kunci. Pengambilan sumber data dilakukan secara purposive dan snowball, teknik pengumpulan dengan triangulasi (gabungan), analisis data bersifat induktif/kualitatif, dan hasil penelitian lebih menekankan makna dari pada generalisasi. ${ }^{4}$

Alasan peneliti menggunakan metode penelitian kualitatif adalah karena objek yang diteliti berupa proses yang sedang berlangsung dan perkembangannya terus diinovasi dalam rangka mengoptimalkan pelaksanaan penilaian dalam Pembelajaran Bahasa Arab Santri Putri Pondok Pesantren Darul Lughah Waddirosatil Islamiyah Akkor Palenga'an Pamekasan. Dengan harapan supaya hasil dari pelaksanaan Penilaian tersebut dapat dijadikan landasan dalam proses belajar mengajar dan penyampaian materi yang sesuai dengan kurikulum. ${ }^{5}$

Penelitian dilaksanakan di Pondok Pesantren Darul Lughah Waddirosatil Islamiyah (DLWI) yang berlokasi di Desa Akkor Kecamatan Palengaan Kabupaten Pamekasan. Dan berfokus pada santri putri di Pondok Pesantren tersebut. Partisipan dalam penelitian ini adalah perancang inovasi penialian (Ustad Rosyid Ridho), salah satu Mudarrisah (Ustadzah Zulaikha), dan tiga orang santri putri yang menjadi peserta penilaian dalam pembelajaran Bahasa Arab santri putri Pondok Pesantren Darul Lughah Waddirosatil Islamiyah Akkor Palenga'an Pamekasa.

Pengumpulan data dikumpulkan melalui teknik observasi dan wawancara. Teknik

\footnotetext{
4 Sugiyono, Metode Penelitian Pendidikan (Bandung: Alfabeta), 15.

5 M. Ainin, Metode Penelitian Bahasa Arab (Malang: Hilal Pustaka, 2007), 10.
}

observasi yaitu teknik pengumpulan data dimana peneliti mengadakan pengamatan secara langsung gejala-gejala subjek yang diselidiki, baik pengamatan itu dilakukan didalam situasi sebenarnya ataupun dilakukan dalam situasi buatan yang khusus diadakan. ${ }^{6}$

Observasi yang dimaksud dalam penelitian ini adalah terjun dan mengamati secara langsung pada saat proses penilaian berlangsung di Pondok Pesantren tersebut, mencoba menggunakan aplikasi yang dijadikan media dalam pelaksanaan penilaian.

Teknik kedua yang digunakan untuk mengumpulkan data adalah teknik wawancara yaitu teknik dimana peneliti mengumpulkan data dengan jalan mengadakan komunikasi langsung dengan objek penelitian, baik didalam situasi yang sebenarnya maupun didalam situasi buatan.

Dan dengan teknik tersebut peneliti mengadakan tanya jawab secara langsung kepada beberapa partisipan, dan menobservasi lagsung lokasi penelitian atau objek penelitian yaitu Pndok Pesantren Darul Lughah Waddirosatil Islamiyah Akkor Palenga'an pamekasan guna mendapatkan data-data yang dianggap penting.

Hasil penelitian ini disusun dengan teknik penyusunan data yang bersifat induktif dan deskriptif. Serta teknik pengecekan keabsahan data melalui; 1) observasi yang diperdalam, 2) memperpanjang kehadiran peneliti di lapangan, 3) memusyawarahkan dengan dosen pembimbing dan teman sejawat.

\section{HASIL DAN PEMBAHASAN \\ Hasil Penelitian}

Pelaksanaan penilaian menggunakan apliksai power point ini pertama kali diterapkan pada kegiatan daurah ramadaniyah (kegiatan kursus bahasa arab yang dilaksanakan khusus dibulan Ramadhan) periode 1440H./2019 M. Pondok Pesantren Darul Lughah Waddirosatil Islamiyah Akkor

\footnotetext{
6 Winarno, Pengantar Penelitian Ilmiah

(Bandung: Trarsito, 1998), 131.

Winarno, Pengantar Penelitian Ilmiah

(Bandung: Trarsito, 1998), 162.
} 
Palenga'an Pamekasan hingga saat ini. Dan sebelum diterapkan inovasi tersebut pelaksanaan penilaian dilaksanakan sebagaimana penilaian biasa di lembaga pendidikan pada umumnya. Yaitu penilaian menggunakan kertas yang berlangsung hingga tahun 2017 M. Karena sejak menginjak tahun pelajaran 2018 para musyrif dan umana ma'had memberi perhatian lebih pada pelaksanaan penilaian yang dirasa tidak ada perubahan.

Setelah diadakan proses evaluasi, kisikisi soal ini masih belum sanggup menjawab keresahan musyrif dan perancang sendiri khususnya terkait pelaksanaan penilaian yang masih tidak sesuai dengan dasar, prinsip dan tujuan penilaian yang sebenarnya. Berangkat dari keresahan yang terus menggelayuti, maka Lr. Rosyid Ridho tergerak untuk merancang instrumen penilaan menggunakan aplikasi Power Point, instrumen menggunakan power point diserap dari kisi-kisi soal yang telah terbentuk pada tahun $2018 \mathrm{M}^{8}{ }^{8}$

"Kita paham, bahwa bahasa merupakan sebuah kompetensi yang tidak mungkin bisa diuji dengan menggunkana multiple choice ataupun butir-butir soal yang tersedia di atas selembar kertas. Jika masih berkenaan dengan aspek kognitif mungkin masih bisa diuji dengan soal pilihan ganda atau soal-soal biasa. Seperti hafalan nahwu, shorrof, ataupun mufradat. Namun jika yang akan diuji adalah maharah kalam yang merupakan aspek psikomotorik, menggunakan soal-soal seperti itu bukan merupakan alat ukur yang susuai. Maka hal ini menjadi tantangan untuk kami agar power point yang kami rancang ini bisa menjadi alat ukur yang akurat dan lebih efisien. Maka dengan dasar kisi-kisi inilah pada tahun 2019 M. Akhirnya kami merancang power point untuk digunakan sebagai media penilaian di Pondok Pesantren Darul Lughah Waddirosatil Islamiyah. Dan sampai sekarang masih terus kami evaluasi.",

Setelah dirasa hasil yang luar biasa dari penggunaannya, maka pihak perancang

\footnotetext{
${ }^{8}$ Rosyid Ridho, Wawancara, Pamekasan, 23 Februari 2020.

${ }^{9}$ Rosyid Ridho, Wawancara, Pamekasan, 23 Februari 2020.
}

merasa tertarik untuk terus menggunakan apliksai power point disetiap pelaksanaan penilaian. Tentunya dengan melaksanakan banyak perubahan-perubahan disetiap tahapnya untuk memaksimalkan kualitas pembelajaran dan kualitas out put dari pesantren PP. DLWI.

Informasi yang tidak kalah penting adalah alasan perancang memilih aplikasi power point sebagai alat untuk menginovasi instrumen penilaian. Alasan perancang memilih aplikasi power point karena aplikasi tersebut dirasa sangatlah simple dan mudah digunakan. Semua musyrif dan peserta didik pun merasa mudah meskipun instrumen ini ternilai baru bagi mereka. Selain karena mudah diaplikasikan, power point juga terasa lebih efisien juga menarik sehingga bisa membangkitkan rasa antusias peserta didik saat melaksanakan penilaian. ${ }^{10}$

Selanjutnya, setelah proses merancang selesai, Lr. Rosyid Ridho memposting hasil rancangannya tersebut (power point) di grup musyrif untuk didistribusikan kepada para musyrif yang akan menjad operator penilaian di kelas masing-masing. Musyrif yang telah mendownload power point tersebut bisa mengoperasikan menggunakan handphone miliknya sebagai media pelaksanaan penilaian, dan sebagian ada juga para musyrif yang memindah file power point tersebut ke laptopnya agar screen tampilannya lebih lebar dan lebih jelas.

Berikut penulis juga paparkan bagaimana tahapan tahapan pelaksanaan penilaian dalam pembelajaran Bahasa Arab santri putri di Pondok Pesantren Darul Lughah Waddirosatil islamiyah Akkor Palenga'an Pamekasan. Tahap pertama dalam proses pelaksanaan penilaian ini adalah musyrif memanggil salah satu nama dari peserta didik di kelas untuk maju dan melaksanakan penilaian, karena memang proses penilaian ini dilakukan face to face antara musyrif dan peserta didik sehingga nantinya akan menghasilkan data yang benarbenar akurat tentang kemampuan keterampilan berbahasa Arab yang dimiliki

${ }^{10}$ Rosyid Ridho, Wawancara, Pamekasan, 23 Februari 2020. 
oleh peserta didik. dalam pelaksanaan penilaian ini peserta didik mendapat lima point pertanyaan yang harus dijawa :

1) Test Istima' (menyimak)

Pertama Istima' (menyimak), dalam point ini peserta didik akan mendengarkan salah satu teks yang telah dipelajari sebelumnya menggunakan headset sebanyak tiga kali. Namun jika satu kali mendengarkan sudah dirasa cukup oleh peserta didik maka boleh hanya mendengarkan satu kali saja tanpa pengulangan.

2) Test Kalam (berbicara)

Point pertanyaan kedua adalah Kalam (berbicara), dalam tahapan ini peserta didik diminta untuk menyampaikan apa yang baru saja didengarnya ditahap sebelumnya sesua dengan tingkat pemahaman peserta ddik masing-masing. Jadi peserta didk tidak mengulang apa yang telah didengarnya namun menyampakan apa yan dipaham dari apa yang telah didengarnya. Disinilah keterampilan berbicara dan mengolah kata peserta didik dinilai.

3) Test Kitabah (menulis)

Selanjutnya pertanyaan ketiga adalah Kitabah (menulis), setelah menyimak, menyampaikan apa yang dipahami dari apa yang telah disimak, selanjutnya peserta didik akan diminta untuk menuliskan apa saja yang masih dapat dia ingat dari teks yang didengarnya tadi.

4) Test Qiro'ah (membaca)

keempat adalah Qiro'ah (membaca), dalam tahap ini peserta didik akan membaca sebuah teks yang telah tersdia dalam slide power point. Teks ini tidak sama degan teks yang didengarnya tadi, namun juga merupakan salah satu dari beberapa teks yang telah dipelajari selama proses pembelajaran berlangsung sebelumnya.

5) Test Qawaid

Dan yang kelima adalah Qawaid. Peserta didik akan diperintah untuk menjawab 5 butir soal tentang qawaid sesuai dengan tingkatan kelasnya. Dan point ini sebenarnya hanya merpakan point tambahan, jadi jika peserta didik mampu menjawab tuntas kelima pertanyaan di point qawaid ini dia akan mendapatkan nilai plus yang akan membantu nilai di point-point sebelumnya. Dan jika peserta didik tidak mampu menjawab, tidak akan mempengaruhi terhadap nilai dari pointpoint sebelumnya. ${ }^{11}$

Point-point inilah yang akan dinilai secara intens oleh para musyrif guna mengetahui sejauh manakah tingkat kemampuan peserta didik dalam pembelajaran Bahasa Arab yang telah diajarkan selama proses pembelajaran. Juga untuk mengetahui sejauh manakah tingkat keberhasilan para musyrif dalam mengajar atau mentransfer keilmuannya pada peserta didik. Dengan proses penialian yang jelas maka akan deketahui pula apa yang seharusnya akan dijadikan bahan evaluasi utnuk diperbaiki ataupun disempurnakan guna meningkatkan mutu dan kualitas dari sebuah lembaga pendidikan, kualitas pembelajaran, kualitas tenaga pengajar, dan kualitas peserta didik di suatu lemaga pendidikan.

Dalam setiap proses akan selalu ada kendala, berikut kami paparkan pula tentang beberapa kendala yang dialami saat pelaksanaan penilaan menggunakan power point.

"Kendala utama dari pelaksanaan penilaian menggunakan power point ini adalah jumlah peserta yang terlalu banyak, dari hasil data di putri ada kelas mubtadi' yang berisi 25-30 peserta, dan itu kelas dengan jumlah paling banyak. Jadi karena ujian denga model seperti ini harus di uji satu persatu, maka kelas yang memiliki peserta 2530 tadi butuh waktu yang sangat lama, sedangkan di kelas yang hanya memiliki jumlah peserta 5 seperti di kelas Mutaqaddim, pelaksnaan penilaian seperti ini sangat-sangat kondusif. Tapi untungnya, di masing-masing kelas musyrifnya ada dua, jadi kelas yang memiliki jumlah peserta banyak seperti mubtadi' tadi bisa dibagi menjadi dua, misalkan dikelas ada 30 jadi musyrif A akan menguji di maharah istima', kalam dan

\footnotetext{
${ }^{11}$ Observasi di kelas Muthawassith pada saat
} pelaksanaan penilaian tanggal 24 Februari 2020, 20.26 
kitabahnya. dan musyrif B yang akan menguji di bagian qiroah, mufradat dan qawaidnya. Jadi hasil nilai yang akan diperoleh akan benar-benar akurat karena diperoleh dari hasil penilaian dengan satu soal dan satu penguji. Kendala tersebut masih sedikit teratasi meski pelaksanaannya tetap tak sekondusif kelas mutaqaddim yang hanya berisi 5 peserta didik saja." 12

Selain berkeluh tentang jumlah peserta didik yang tinggi, musyrif lain juga merasakan kendala pada tingkat kemampuan peserta didik yang di ampunya, sebagai berikut

"Kendalanya lebih ke kemampuan peserta didik, karena kemampuan per individu tidak sama, jadi kendalanya disana yang mampu enak, bebas kendala, kalau yang kurang mampu ini lumayan berkendala. Jadi kendala yang saya rasakan saat pelaksanaan penilaian berlangsung lebih karena kendala SDM peserta didik aja. Bukan dari aplikasi dan pelaksanaannya." 13

\section{Pembahasan}

Dalam sebuah proses inovasi pasti ada tujuan yang melatar belakanginya, berikut menurut Santoso (1974), dalam buku Fuad Ihsan tujuan utama inovasi, yakni meningkatkan sumber-sumber tenaga, uang dan sarana, termasuk struktur dan prosedur organisasi serta meningkatkan efisiensi, relevansi, kualitas dan efektifitas : sarana serta jumlah peserta didik sebanyakbanyaknya, dengan hasil pendidikan sebesarbesarnya (menurut kriteria kebutuhan peserta didik, masyarakat, dan pembangunan), dengan menggunakan sumber, tenaga, uang, alat, dan waktu dalam jumlah yang sekecilkecilnya. $^{14}$

Selanjutnya adalah teori tentang dasardasar dari dilaksanakannya sebuah inovasi, dalam bukunya, Hasbullah menuliskan dasardasar inovasi antara lain; 1) perkembangan ilmu pengetahuan dan teknologi

${ }^{12}$ Rosyid Ridho, Wawancara, Pamekasan, 23 Februari 2020.

${ }^{13}$ Siti Zulaikhah, Wawancara, Pamekasan, 25 Februari 2020.

14 Fuad Ihsan, Dasar-Dasar Kependidikan, (Jakarta:PT Rineka Cipta: 2011), 192.
2) pertumbuhan penduduk

3) meningkatkan animo masyarakat untuk mendapatkan pendidikan yang lebih baik

4) menurunnya kualitas pendidikan

5) kurang adanya relevansi antara pendidikan dan kebutuhan masyarakat yang membangun

6) Belum mekarnya alat organisasi yang efektif serta belum tumbuhnya suasana yang subur dalam masyarakat untuk mengadakan perubahan-perubahan yang dituntut oleh keadaan sekarang dan yang akan datang. ${ }^{15}$

Berangkat dari beberapa teori tersebut maka hasil rancangan Power Point sebagai media penilaian yang digunakan di Pondok Pesantren Darul Lughah Waddirosatil Islamiyah sudah layak untuk dikatakan sebagai sebuah inovasi. Fakta lapangan yang kami temukan juga selaras dengan fungsi, tujuan serta prinsip-prinsip inovasi yang ada dalam teori. Pondok Pesantren Darul lughah Waddirosatil Islamiyah ini melaksanakan inovasi di ranah media penilaian dalam pembelajaran Bahasa Arab menggunakan power point guna mengejar ketertinggalan terhadap ilmu pengetahuan dan teknologi yang semakin pesat perkembangannya, sebagai bentuk meningkatkan mutu atau kualitas pendidikan khususnya dalam pembelajaran Bahasa Arab, serta untuk spesifikasi media yang akan digunakan untuk mengukur sejauh mana tingkat kesuksesan peserta didik dalam memperoleh dan memahami bahan ajar yang telah diajarkan sebelumnya, serta mengukur sejauh mana kesuksesan tenaga pendidik mentransfer keilmuannya. Demi mendapatkan hasil terbaik dari pelaksanaan penilaian tersebut, maka diinovasilah atau diperbaharuilah media penilaiannya.

Hasil dari proses inovasi tersebut sudah bisakah digunakan sebagai media penilaan? jika kita memperhatikan teori yang mengatakan bahwa Secara umum yang dimaksud dengan instrumen adalah suatu alat yang memenuhi persyaratan akademis sehingga dapat dipergunakan sebagai alat untuk mengukur suatu objek ukur atau mengumpulkan data mengenai suatu veriabel.

${ }^{15}$ Hasbullah, Dasar-Dasar Ilmu Pendidikan, (Jakarta: PT. Grafindo Persada, 2006), 191. 
Dalam bidang pendidikan instrumen disebut juga alat untuk menilai atau mengukur prestasi belajar siswa, faktor-faktor yang diduga mempunyai hubungan atau berpengaruh terhadap hasil belajar, perkembangan hasil belajar siswa, keberhasilan proses belajar mengajar guru, dan keberhasilan pencapaian suatu program tertentu. $^{16}$ Maka hasil inovasi penilaian menggunaka power point ini sudah memenuhi syarat untuk dijadikan media dalam sebuah pelaksanaan penilaian.

Yang perlu diketahui juga adalah tentang baik atau tidakkah hasil rancangan inovasi tersebut jika ditilik dari kegunaannya sebagai media penilaian. Berikut kami paparkan ciri-ciri media penilaian yang baik;

1) shahih (validitas)

2) konsisten (reliabilitas)

3) objektifitas

4) praktibilitas

5) ekonomis

6) taraf kesukaran

7) daya pembeda.

Setelah memperhatikan fakta lapangan dari pelaksanaan dan penggunaan aplikasi power point tersebut, menurut peneliti, aplikasi tersebut layak dikatakan sebagai media penilaian yang baik dengan beberapa alasan berikut;

Pertama, karena validnya hasil yang diperoleh saat mengukur tingkat kemampuan empat maharah dan qawaid yang dimiliki peserta didik, maksudnya hasil dari penilaian menggunakan media berupa aplikasi power point ini sangat sesuai dengan fakta kemampuan anak didik tersebut dan dapat dipertanggungjawabkan.

kedua, aplikasi tersebut sangat konsisten karena hanya bermata satu, artinya seluruh peserta didik di kelas tersebut (satu tingkatan) diuji dan dinilai menggunakan soal yang sama satu sama lain. Jadi kemampuan seluruh peserta didik di tingkatan tersebut diukur oleh alat ukur yang sama. Hal ini

${ }^{16}$ Ramli Abdullah, "Urgensi Penilaian Hasil Belajar Berbasis Kelas Mata Pelajaran IPS di Madrasah Tsanaeiyah", Lantanida Journal, Vol. 03, No. 02 (2015), 171. berdampak baik untuk ke-konsistenan hasil yang diperoleh.

Ketiga, keempat dan kelima, Tidak hanya konsisten, alat ukur ini juga objektif, praktis dan ekonomis. Karena nilai yang akan diperoleh bergantung pada kemampuan peserta didik menyelesaikan pertanyaanpertanyaan yang tersedia dalam slide-slide power point. Praktis karena tidak membutuhkan banyak hal untuk pelaksanaannya dan ekonomis karena sangat menghemat biaya maupun tenaga.

Dan terakhir, aplikasi power point ini juga memiliki daya pembeda dan taraf kesukaran karena soal-soal yang tersedia sudah dibagi pada masing-masing kelas atau tingkatan. Jadi untuk kelas mubtadi' soalnya berbeda dengan kelas mutaqaddim. Soal untuk kelas mutaqaddim berbeda dengan soal untuk kelas i'dad. Dan sebagainya.

Maka berdasarkan fakta dan teori tersebut, dapat peneliti simpulkan bahwa inovasi penilaian menggunakan power point ini merupakan sebuah inovasi dari sebuah instrumen penilaian yang berkualitas baik bahkan sangat baik dan layak diperhatikan atau bahkan dicontoh dan diteladani oleh para penyelenggara pendidikan secara umum, lebih-lebih penyelenggara pembelajaran Bahasa Arab diluar sana.

\section{SIMPULAN}

Proses terancangnya inovasi penilaian menggunakan aplikasi power point ini berawal dari keresahan mudarris karena melihat alat ukur yang digunakan dalam pelaksanaan penilaian bukan alat ukur yang sesuai. Pada tahun 2018 muncullah ide dan gagasan untuk menginovasinya dengan memunculkan kisi-kisi untuk memperjelas tujuan dan target penilaian terlebih dahulu. Dan akhirnya, pada tahun 2019 lahirlah aplikasi power point yang dapat digunakan sebagai alat ukur dalam pelaksanaan penilaian tersebut, dengan praktik pelaksanaan sebagai berikut ;

1) Test istima' : Peserta didik diminta untuk menggunakan headset untuk mendengarkan audio yang diputar dari handphone/laptop oleh mudarris. Hal ini di ulang tiga kali. 
2) Test kalam : peserta didik diminta untuk menyampaikan tentang apa yang berhasil dia paham dari audio yang telah didengar sebelumnya.

3) Test kitabah : peserta didik diminta untuk menuliskan apa yang berhasil dia ingat dari audio yang telah di dengar sebelumnya.

4) Test qiro'ah : peserta didik diminta untuk membaca teks yang telah tersedia di slide power point yang ditunjukan oleh mudarris.

5) Test pemahaman qawaid : peserta didik diminta untuk menjawab secara lisan pertanyaan tentang qawaid yang tersedia dislide power point yang ditunjukan oleh mudarris.

Dengan tujuan dan target yang jelas, pelaksanaan penilaian menjadi lebih terarah. Hasil dari pelaksanaan penilaian dapat dipertanggungjawabkan juga pelaksanaan penilaian menjadi lebih menarik hingga berhasil memancing rasa antusias peserta didik untuk belajar bahasa Arab. Media penilaian yang praktis dan efisien ini juga sangat mudah untuk dibawa kemanapun tanpa takut tertinggal lebih-lebih sampai hilang. Jadi dapat disimpulkan bahwa inovasi penilaian menggunakan power point ini merupakan sebuah inovasi media penilaian yang berkualitas baik bahkan sangat baik serta layak diperhatikan atau bahkan dicontoh dan diteladani oleh para penyelenggara pendidikan secara umum, lebih-lebih penyelenggara pembelajaran Bahasa Arab secara umum.

\section{DAFTAR PUSTAKA}

Abdullah, Ramli. "Urgensi Penilaian Hasil Belajar Berbasis Kelas Mata Pelajaran IPS di Madrasah Tsanawiyah". Lantanida Journal, Vol. 03, No. 02 (2015).

Arifin, Zainal. Evaluasi Pembelajaran. (Jakarta: PT Remaja Rosadakarya: 2013).

Hasbullah. Dasar-Dasar Ilmu Pendidikan. (Jakarta: PT. Grafindo Persada, 2006).
Hasil observasi di kelas Muthawassith pada saat pelaksanaan penilaian tanggal 24 Februari 2020, 20.26

Ihsan, Fuad. Dasar-Dasar Keperndidikan. (Jakarta:PT Rineka Cipta: 2011).

M. Ainin. Metode Penelitian Bahasa Arab. (Malang: Hilal Pustaka, 2007).

Misbah, Dodi. dkk, "Penggunaan Media Audio Visual dalam Pembelajaran yang Berbasis Power Point Model Pop Up untuk Meningkatkan Hasil Belajar Siswa pada Mata Pelajaran Bahasa Arab". Jurnal Teknologi dan Pembelajaran. Vol. 2, No. 2 (September, 2017).

Rahmadani, Nur. Dkk. "Keaktifan Penggunaan Media Microsoft Power Point dalam Pembelajaran Kosakata (Mufradat) Bahasa Arab Kelas X SMA Negeri 5 Barru". (Makkassar: Universitas Negeri Makassar, 2019).

Ridho, Rosyid. Wawancara, Pamekasan, 23 Februari 2020.

Sugiyono. Metode Penelitian Pendidikan. (Bandung: Alfabeta).

Tamba, Rosalina. "Jurnal Upaya Meningkatkan Keterampilan Mengajar Guru dengan Menggunakan Power Point di SD No.097803 Tanjung Mariah Tahun Pelajaran 2015/2016". Vol.6, No.01 (Januari-Juni, 2017).

Tayibnapis, Farida Yusuf. Evaluasi Program. (Jakarta: PT. Rineka Cipta, 2000).

Winarno. Pengantar Penelitian Ilmiah. (Bandung: Trarsito, 1998). 